\title{
The Effect Of Leadership Style, Determination Of Strategic Change On Implementation In Telecommunication Companies In Kenya
}

\author{
Yusuf Mohamed Ahmed, James Mbebe and Dr. Wilson Muema \\ DOI: 10.29322/IJSRP.10.08.2020.p104107 \\ http://dx.doi.org/10.29322/IJSRP.10.08.2020.p104107
}

\begin{abstract}
The telecommunication companies over the globe are growing very fast and this has been attributed to the strategic planning and implementation of growth strategies. Despite the industry experiencing a boom in the recent past, only a handful of scholarly studies have been conducted in Kenya to capture these growth moments and make sense of them. They key determinants for success of implementation of strategic plan are the government policies, leadership style, marketing positioning and the organizational structure among others. Essentially, the study sought to bring out the how these determinants predict the implementation of strategic change with focus on telecommunication entities in Kenyan context. The study targeted 562 senior managers of the three main telecommunication players in the Country namely Safaricom, Airtel, and Telekom Kenya. Approximately 234 managers from the three companies were sampled and a questionnaire that had been pretested and validity and reliability tested were administered. Data collected was entered into a spread sheet, cleaned and then analyzed. Descriptive data analysis was conducted and results given in tables and figures. Inferential statistics were calculated using SPSS version 22 to calculate the correlation and regression analysis for drawing of inferences. A statistically significant link of government policy, market positioning, leadership style and organizational structure on implementation of strategic change in Telecommunication Companies in Kenya was noted. It was recommended that telecommunication companies to consider government involvement in commercial activities enhance market positioning practices and ensure strategic structure alignment is enhanced to have an effective strategic change implementation.
\end{abstract}

Index Terms- Leadership style, Strategic change and implementation

\section{INTRODUCTION}

G lobally, the telecommunication industry has been developing anonymously in the past three decades. Within this period the extent of people who have been getting to telecom industry has also been on the rise. Various people have had the choice to get to cell phones, broadband and fixed phone lines. In this manner, various countries are setting resources into the business as a methodology for pushing cash related development (Caroline, 2016). China and India are among the best and speediest making economies on earth today, which offer some strategic standard parts. The telecom business is an interesting industry to consider, not by virtue of its irregular nature to the degree mechanical advance and its strategies, yet in like way in setting on the high progress pace of this industry all through late decades and the titanic responsibility of the business to the economies of these countries. China is immediate the world's most huge telecom pitches and as appeared by specialists' figures, there are more than 1.25 million cell supporters joining each week (Pyramid, 2015). In the meantime, India has changed into the strongest making telecom markets with a common improvement pace of over $26 \%$ and passed on business open entryways for around 10 million people.

Strategy implementation as indicated by Gabriel and Kazanjian (2016) includes the improvement of structures and strategies in an organization. Implementation on the other hand is a strategic stage and in the strategy that cannot be directionless anyway as a rule ignored. In addition, consequently being a determinant of implementation, there is having to define strategies that could trigger more prominent performance when viably actualized. Strategic arranging and performance should join depictions of the various models that could show the organizations characteristics which will enable the implementation to gathering to make effective strategies for implementation.

\section{PAST STUDIES}

\section{Leadership Style}

Musyoka (2017) looked at the styles of leadership and their link with implementation of strategies with a focus on the hotel sector. The specific focus if the study was on Safari Park Hotel. The adopted design was descriptive and 59 staff were targeted and censured. It was shown that transformational, democratic and charismatic styles of leadership were all applied at the Safari Park Hotel. It was indicated that existence of good channels of communication enhances the implementation of strategies. The issues and concerns raised include the need to have in place clear channels of communication between the management team and the staff in the organization.

Inyang, Agnihotri and Munoz (2018) looked at the style of leadership of the manager and the role it plays as far as the implementation of the sales strategy in the entity is concerned. The study covered a total of 190 respondents and it included development and testing of hypotheses. It was shown that transformation style of leadership and the implementation of strategies are linked with each other. Furthermore, it was shown that the implementation of the strategy for sales directly predict 
performance of sales. The implications that were raised from the inquiry included the fact that the sales managers are required to ensure that their style of leadership has been adapted on the competitive environment which they carry out their operations.

Tawse (2018) did an inquiry into the style of leadership where the subjects are involved to participate in the activities and how this boosts the need to ensure that strategies have been actualized. Besides actualization of the strategies formulated as one of the variables. The other variable was the ability of the firm to perform. The context of the inquiry was in United States of America. Among the constructs that were considered by the inquiry include the structure of the entity, the degree of involvement and the success in actualization of the strategies formulated. It was shared that having a culture where participants are involved in the activities of the actualization of the strategies boosts the degree of success.

Koech and Namusunge (2012) did an inquiry into the styles of leadership and their link with the ability of the firm to perform. The key area of concern in the inquiry was on corporations in the public domain covering the county of Mombasa. The constructs adopted in the inquiry included transformation and autocratic style of leadership. It was shown that free reign and the ability of the firm to perform are not linked with each other in significant terms. Anita, Wachira and Mwendas (2015) concentrated on the smaller firms with operations in Nairobi and looked at the style of a leader and its link with the ability of the firm to implement its strategic plan. The design used was descriptive. In total, 354 entities were covered by the inquiry. The key constructs of the style of leadership examined by the investigation include the ability to supervise, responsibility of the manager to the activities of the entity and the ability to exercise discipline. A positive link was noted between autocratic style of leadership and the ability of the firm to implement strategies. In agreement with these views, Murigi (2013) did an inquiry into autocratic style of leadership and the role it plays in ability of the entity to perform. It was shared that autocratic style of leadership covers the ability to exercise discipline, supervise and command. Thus, the key emphasis of the leader with autocratic attributes is to ensure that the key tasks in the entity have been completed as planned.

Ngetich and Maina (2014) did an inquiry into the style of leadership and the link with implementation of strategies. The key styles of leadership that were covered in the inquiry include participative, autocratic, free reign and democratic styles. In total, 320 staff targeted from senior positions was targeted in the inquiry. The focus of the inquiry was on KRA and it was shown that autocratic leadership Style has positive relationship on strategy implementation at KRA.

Allameh (2015) did an undertaking on the styles of leading and the actualization of the strategies in the Iranian context. It was shared that the style of leading adopted in the entity goes a long way to ensuring that the strategies formulated have been actualized. Ghamrawi (2013) undertook to bring out the link between the style of leadership and the ability to actualize ICRT activities in the learning institutional context. It was noted that an entity having managers who are autocratic will have its strategies adversely affected at the actualization phase.

Awino (2017) did an inquiry into identified variables and their link with the ability of the body corporate to perform. The scope of the inquiry was on relatively larger manufacturing entities in Kenyan context. The adopted design was descriptive also including the use of surveys. These were meant to bring out the link between variables. Views were gathered as supported by first hand as well as auxiliary sources. It was found out that it is only good leadership which can ensure effective implementation of strategies. Awino (2017) further urged that the top management led by the CEO, must commit everything for strategy implementation to be a success, and this includes involving all members from staff.

Ndunge (2014) studied the job of a leaders with strategic considerations and change at the Kenya Wildlife Service. The study used a graphic research plan and essential data was gathered utilizing a semi-organized survey. The study found that strategic leadership affected implementation of progress the board rehearses at the Kenya Wildlife Service. It is of importance for the leaders in the entity to ensure that various resources have been availed and that the vision of the entity has been shared to all other the staff. At the same time, the leaders should be dedicated to the need to actualize the strategies while buying all the new issues that are so diverse. The direct link between actualization of the change in the strategic dimension and the style of the leader is also supported by Bhargara (2013) who noted that when the management of the firm is effective, the change initiatives from a strategic angle are also strengthened.

Murigi (2013) was keen to bring out the leadership traits of the school head and how they predict the ability of learners to perform. The scope and focus of the inquiry was on Muranga. The key emphasis of the inquiry was on autocratic style of leadership with its measures covering the ability to supervise, direct, arrange tasks and instill discipline. It was noted that that individual who lead autocratically largely place emphasis on their roles as managers (mean =4.9) and getting things done $($ mean=4.2). It was shown through the leadership of autocratic style; the staffs are motivated as the leader provides discipline to students. Surprisingly, this autocratic style of leadership was seen to have least link on performance of the learners.

Michira and Anyieni (2018) focused on leadership and the role it plays as fat as the implementation of strategic plans is concerned. The specific reference of the study was on Mwalimu SACCO. The upper echelon provided anchorage to the inquiry and the adopted design was survey. Leveraging on information gathered from primary sources, it was noted that the style of the leader will directly boost the ability of the organization to implement the strategic plans. Among the styles of leadership noted to have been adopted in the firm include democratic, transactional and transformational. However, there were some managers who practiced autocratic style of leadership. From the above review, the findings portray that strategic leadership assume a significant job in predicting the degree which an entity actualizes the tactics. The sort of style of leading, correspondence approach and organizational assets profoundly shape the ability of the tactics to perform in an entity. Despite the fact that broad research has been done because of strategic leadership on approach implementation, restricted focus has been laid on telecommunication companies in the country. This study endeavors along these lines, to connect this hole by deciding the relationship between implementation of strategic change and performance of telecommunication companies in Kenya. 


\section{METHODOLOGY}

\section{A Research Design}

The adopted design in this inquiry was descriptive. It was through this design that it was possible for the inquiry to provide a summary of information on the respondents. Through this descriptive design, it is possible for an investigation to provide a narration on the way things are in their present state

\section{B Target Population}

Target population describes the items and events that form the basis for generalization of the evidence sought in the inquiry (Burns, 2010). The researcher should strive to find out a possible element about the study population which includes age, gender and classes of the population. The inquiry targeted 562 senior managers in the three telecommunication companies in Kenya as shown in table 3.1 where the study was based at the Safaricom, Airtel and Telkom Company.

Table 3.1: Target Population

\begin{tabular}{ll}
\hline Company & Population \\
\hline Safaricom Ltd & 386 \\
Airtel & 73 \\
Telecom & 103 \\
Total & $\mathbf{5 6 2}$ \\
\hline
\end{tabular}

Source: HR depts in Safaricom, Airtel and Telecom, (2019)

\section{Sample and Sampling Technique}

The sampling was done using the stratified random sampling design. The stratified method was used in this study because the population had several managerial levels which were used as strata. Random sampling was then used to select a sufficient number of subjects from each stratum by picking the respondents randomly.

A total population of 562 management staff at Safaricom, Airtel and Telkom Company was used. Yamane (1967:886) came up with a sample size selection formula which was used in this study. $\mathrm{n}=$ desired sample, $\mathrm{N}=$ accessible population size, e=desired level of precision (0.05).

$\mathrm{n}=\mathrm{N} / 1+\mathrm{N}(\mathrm{e})^{2}$

$\mathrm{n}=562 / 1+562(0.05)^{2}$

$\mathrm{n}=562 / 1+562(0.0025)$

$\mathrm{n}=562 / 1+1.405$

$\mathrm{n}=562 / 2.405$

$\mathrm{n}=234$

\section{Data Collection Instruments}

The views in response to the research questions in this investigation were gathered from first hand sources. In essence, the questionnaires were adopted. Most of the items on the tools required fixed responses from the participants in the inquiry. This was meant to give easier time to the team charged with processing these views into meaningful insights (Mugenda \&Mugenda, 2012). There were different sections that were included in the tool of gathering the opinions of the participants. In first area, the key details of the participants were capture while the other areas covered information on the study objectives. Some of the items on the questionnaire was rated on a Likert system. This was meant to ease the entire process of analysis of the views of the respondents.

In administering the tools to the participants, efforts were made to ensure that each of them has been given adequate time to ponder about the items raised. This meant administering the items and then picking them at a later date. The details of the participants were captured and follows ups were made to ensure each of the item had been filled. This also gave the researcher ample time to respond to any concerns being faced by the participants in the inquiry as they capture their views on the tools.

\section{RESULTS AND DISCUSSION}

\section{A Demographic information}

The study findings show that female respondents were $29.29 \%$ while the male respondents were $60.71 \%$ of the 168 respondents who participated in the study. It shows that there are more males than females in the three management levels in telecommunication companies in Kenya. The findings show that the age of 30-34 years constituted $45.5 \%$ of the participants in the inquiry. Those in the age of bracket $35-39$ years were $25.6 \%$ while below 30 years were $12.5 \%$. Those in age bracket between 40 and 44 years were $8.90 \%$. The findings imply that majority of managers in the three management levels are above 35years of age.

\section{B Descriptive Analysis}

The descriptive processing of the views of the participants on the independent variables (government policy, market positioning, leadership style and organizational structure) and dependent variable (strategic change implementation) of the study are documented in this section.

Leadership Style and Strategic Change Implementation

Leadership style was one of the study variables and Table 4.10 reports the descriptive statistics. 
Table 1 : Influence of leadership style on strategic Change implementation

\begin{tabular}{|c|c|c|c|c|c|}
\hline & 5 & 4 & 3 & 2 & 1 \\
\hline $\begin{array}{l}\text { Level in the company in which } \\
\text { management and control of the } \\
\text { strategic change implementation } \\
\text { process occur }\end{array}$ & 37.4 & 39.3 & 12.5 & 6.3 & 4.5 \\
\hline $\begin{array}{l}\text { Level of involvement by } \\
\text { people/departments are in guiding the } \\
\text { strategic change implementation } \\
\text { process }\end{array}$ & 32.7 & 42.3 & 7.2 & 12.6 & 5.2 \\
\hline $\begin{array}{l}\text { Management regularly updates } \\
\text { employees about the plans and } \\
\text { progress toward the change } \\
\text { implementation. }\end{array}$ & 31.6 & 37.8 & 16.4 & 9.3 & 4.9 \\
\hline $\begin{array}{l}\text { Leadership style which led to the most } \\
\text { effective implementation of strategic } \\
\text { change in your company }\end{array}$ & 30.9 & 39.3 & 8.9 & 14.2 & 6.7 \\
\hline
\end{tabular}

\section{Source: Research Data (2020)}

In regard to the level in the company in which management and control of the strategic change implementation process occurs respondent were asked to indicate their responses using nominal codes of $1-5$ where ; $5=$ top level, $4=$ Middle Level, $3=$ Functional Level, 2=Others and 1= Impossible to tell. $37.4 \%$ of the respondents indicated top level, 39.3\% middle level, $12.5 \%$ functional level, $6.3 \%$ other levels and $4.5 \%$ indicated it was impossible to tell which level the telecommunication company strategic implementation process occurred. Respondents were asked state whether the management regularly updated employees about the plans as well as progress made towards realization of change in strategic view in the telecommunication company, $31.6 \%$ of the participants in the inquiry were in strong agreement, $37.8 \%$ agreed, $16.4 \%$ indicated neutral, $9.3 \%$ disagreed and 4.9 strongly disagreed. In regard to the leadership style which enhanced the effectiveness of implementing change from a strategic point, respondents were asked to indicated with nominal codes $1-5$ where $5=$ Authoritarian, $4=$ Democratic, 3=Laissez Faire, $2=$ Bureaucratic and $1=$ Neurocratic. $30.9 \%$ of the respondents indicated authoritative, 39, 3\% democratic, $8.9 \%$ laissez faire, $14.2 \%$ bureaucratic and $6.7 \%$ indicated neurocratic leader

\section{CONCLUSIONS}

\section{Leadership style and strategic change implementation}

The investigation was keen to bring out the underlying link between the style of leading and the need to ensure that change from strategic point of concern has been actualized in an entity. The area of emphasis of the investigation was entities carrying out activities in the telecommunication segment of the Kenya. It was shown one of the adopted styles of leadership was democratic b and it was characterized by high level of communication. The major finding on leadership styles was that a democratic leader is one who is able to communicate well and this is among the style of leadership that are highly desired. Middle level employees' ability to engage in decision making process was fundamental to such leadership in telecommunication companies having a significant influence in the implementation of strategic change. It is important to ensure that the senior managers have been involved in the implementation of strategic issues in the entity. This will give the senior managers an opportunity to collaborate and work together with other staff for the sake of attainment of the key goals of the entity. Bhargara (2013) noted that well-functioning managerial units ensure that their strategic considerations have been strengthened while enriching the tasks and activities of other staff in the entity. It can therefore be shown that the structure of the entity is among the determinants when the firm is striving to implement change in the strategic dimension.

\section{REFERENCES}

[1] Awino, Z.B. (2017). The effect of selected variables on corporate performance: A survey of supply chain management in large private manufacturing firms in Kenya, Published Thesis, University of Nairobi 
[2] Ayham A. M., 2014. Change Management in Telecommunication Sector: a Managerial Framework. Review of Contemporary Business Research Vl. 3

[3] Brenes, E.R., Mena, M., \& Molina, G.E. (2008). Strategic Success Factors for Strategy Implementation in Latin America. Journal of Commercial Research, 61(6), 590- 598

[4] Buysee \&Verbeke (2013). Proactive environmental strategies - a stakeholder management perspective in Belgium. Academy of Management Review, Vol. 21 No. 1, pp. 173-202.

[5] Caroline, K.Y. (2017), 'Implementation of KM Strategies in the Malaysian telecommunication industry; An empirical analysis', Journal of Information and Knowledge Management systems, 37 (4), pp. 452-470.

[6] Corboy and Corrbui, (2014), 'A New Model for Competitive Warfare and Sustained Advantage', Strategic Change, 17, pp. 269-280.

[7] Farh, J. L., \& Cheng, B. S. 2000. A cultural Analysis of Paternalistic Leadership in Chinese Organizations. In J. T. Li., A. S. Tsui, and E. Weldon (Eds.), Management and Organizations in the Chinese context. London: Macmillan.

[8] Gabriel \&Kazanjian (2016),Strategic Management Concepts, 12th e.d, London: Pearson.

[9] Hill, J. W. \& Jones, G. (2010), Strategic management theory: An integrated approach, 9th Ed. Boston: Houghton-Mifflin.

[10] Iacobucci, D. \& Churchill, G.A., 2010. Marketing research methodological foundations -international edition, 10th edition, Hampshire: South-Western Cengage Learning.

[11] Khayota O.M. (2014). Critical Analysis of Strategy Implementation on Organization Performance in Service Delivery: Case of Lake Victoria South Water Services Board in Kisumu. Vol.6, No.30, 2014. 192-208

[12] Koech, P., \&Namusunge, G. S. (2012). Effect of leadership styles on organization performance at State Corporation in Kenya. International Journal of Commercial and Commerce, 2(1), 1-12.

[13] Kothari, P. (2004),Research Methodology, 4th Edition, New Age Internal Publishers, New York, USA

[14] Lufthans, G. (2012). Transforming organizations to transform society. In Kellog leadership studies project. Transformational leadership working papers, University of Maryland: The James McGregor Burns Academy of leadership.

[15] Markiewicz, P. (2011). Change Management in the Implementation of Strategic Plans Process. IntelektineEkonomika, 5(2), 257-267.

[16] Muhoro, J. (2011).The effect of leadership in strategic change implementation in Telkom Kenya, Unpublished MBA Project, University of Nairobi

[17] Murigi, M. W. (2013). Influence of Head Teacher Leadership Styles on Pupils performance in Kenya Certificate

[18] Ndunge, W. E (2014). Strategic leadership and change management practices at the Kenya wildlife service, Unpublished MBA Project, University of Nairobi

[19] Ogbeide, G. C.,\& Harrington, R. (2011). The Relationship among Participative Management Style. International Journal of Management, 50 (10), 1-9

[20] Pyramid, A. (2018). Linking Strategy to Operations: Six Stages to Execution. Business Performance Management, 6(4), 10-13.

[21] Ronald, J.B. (2011).The Effect of Leadership Style On employee Satisfaction and Performance of Bank Employees in Bangkok. Journal of Commercial and Psychology, 111-116.

[22] ISchultz, D. \&Hekman, R. (2016).Stakeholder theory and managerial decision-making with a bias on constraints and implications of balancing stakeholder interests. Organizational Dynamics, Vol. 22 No. 3, pp. 20-32

[23] Tourish, L. (2015). The Drivers and Inhibitors of Strategy Execution. Gordon Institute of Business Studies: Pretoria.

[24] World Investment Report (2015), Reforming International Governance

\section{AUTHORS}

First Author - Yusuf Mohamed Ahmed

Second Author - James Mbebe

Third Author - Dr. Wilson Muema 